\title{
Extracts from tumors causing oncogenic osteomalacia inhibit phosphate uptake in opossum kidney cells
}

\author{
K B Jonsson ${ }^{1}$, M Mannstadt ${ }^{1,2}$, A Miyauchi ${ }^{3}$, I M Yang ${ }^{4}$, \\ G Stein ${ }^{5}$, Ö Ljunggren ${ }^{6}$ and $\mathrm{H}$ Jüppner ${ }^{1,2}$ \\ ${ }^{1}$ Endocrine Unit, Department of Medicine, Massachusetts General Hospital and Harvard Medical School, Boston, Massachusetts 02114, USA \\ ${ }^{2}$ MassGeneral Hospital for Children, Massachusetts General Hospital and Harvard Medical School, Boston, Massachusetts 02114, USA \\ ${ }^{3}$ Department of Medicine, Kobe University School of Medicine, Kusunoki-cho, Chuo-ku, Kobe 650, Japan and National Sanatorium, Hyogo Chuo Hospital, \\ 1314 Ohara, Sanda 669-1515, Japan \\ ${ }^{4}$ Department of Internal Medicine, Kuyunghee University, Seoul, Korea \\ ${ }^{5}$ Klinik für Innere Medizin, Friedrich-Schiller-Universität, Jena, Germany \\ ${ }^{6}$ Department of Medical Sciences, University of Uppsala, Uppsala 751 85, Sweden \\ (Requests for offprints should be addressed to K B Jonsson, Massachusetts General Hospital, Endocrine Unit, 50 Blossom Street, WEL 501, Boston, \\ Massachusetts 02114-2698, USA; Email: Kenneth.Jonsson@medicin.uu.se)
}

\begin{abstract}
In oncogenic osteomalacia (OOM), a tumor produces an unknown substance that inhibits phosphate reabsorption in the proximal tubules. This causes urinary phosphate wasting and, as a consequence, hypophosphatemic osteomalacia. To characterize this poorly understood biological tumor activity we generated aqueous extracts from several OOM tumors. Extracts from three of four tumors inhibited, dose- and time-dependently, ${ }^{32} \mathrm{P}-$ orthophosphate uptake by opossum kidney (OK) cells; maximum inhibition was about $45 \%$ of untreated control. Further characterization revealed that the factor is resistant to heat and several proteases, and that it has a low molecular weight. The tumor extracts also stimulated cAMP accumulation in OK cells, but not in osteoblastic ROS 17/2.8 and UMR106 cells, or in LLC-PK1 kidney cells expressing the parathyroid hormone $(\mathrm{PTH}) / \mathrm{PTH}-$
\end{abstract}

related peptide receptor or the PTH-2 receptor. HPLC separation of low molecular weight fractions of the tumor extracts revealed that the flow-through of all three positive tumor extracts inhibited ${ }^{32} \mathrm{P}$ uptake and stimulated cAMP accumulation in OK cells. Additionally, a second peak with inhibitory activity on phosphate transport, but without cAMP stimulatory activity, was identified in the most potent tumor extract. We have concluded that several low molecular weight molecules with the ability to inhibit phosphate transport in $\mathrm{OK}$ cells can be found in extracts from OOM tumors. It remains uncertain, however, whether these are related to the long-sought phosphaturic factor responsible for the phosphate wasting seen in OOM patients.

Journal of Endocrinology (2001) 169, 613-620

\section{Introduction}

Parathyroid hormone (PTH) and the biologically active vitamin $\mathrm{D}$ metabolite, 1,25 dihydroxyvitamin $\mathrm{D}_{3}$ $\left(1,25(\mathrm{OH})_{2} \mathrm{D}_{3}\right)$ are the two major hormonal regulators of phosphate homeostasis. PTH decreases the tubular reabsorption of phosphate by accelerating the degradation of the type II sodium-dependent phosphate transporter (NPT-2) (Murer et al. 1999), the most important phosphate transporter in the proximal tubules. $1,25(\mathrm{OH})_{2} \mathrm{D}_{3}$ does not have a direct role in renal phosphate handling but enhances phosphate uptake from the gut. However, changes in the levels of these two hormones do not explain the dramatic increase in renal reabsorption of phosphate in response to phosphate starvation, suggesting that additional factors are involved in the regulation of this mineral (Drezner 1996).

Studies of X-linked hypophosphatemic rickets (XLH), a rare genetic disorder, and the corresponding animal models, the $g y$ and hyp mice, have recently yielded new important insights into the regulation of phosphate homeostasis (Econs 1999, Tenenhouse 1999, Drezner 2000). XLH is a renal phosphate wasting disease with associated hypophosphatemic rickets. Characteristic biochemical findings include hyperphosphaturia, hypophosphatemia, and inappropriately low circulating levels of $1,25(\mathrm{OH})_{2} \mathrm{D}_{3}$ (Tenenhouse 1999). The mutated gene responsible for the disease, PHEX, encodes a membrane- 
bound neutral endopeptidase that is not expressed in the kidney (Ruchon et al. 1998, Du et al. 1996, Beck et al. 1997). To explain how mutations in this gene can cause phosphaturia it was necessary to invoke the actions of a yet-unidentified hormonal factor, provisionally referred to as phosphatonin, with the ability to decrease directly renal tubular phosphate reabsorption in the kidney (Econs \& Drezner 1994). The currently prevailing hypothesis thus suggests that PHEX inactivates phosphatonin and that loss-of-function mutations in this enzyme increase the levels of phosphatonin in the circulation.

Similarly, increased concentration of a phosphaturic factor has been implicated in the pathogenesis of oncogenic osteomalacia (OOM), an acquired condition characterized by phosphopenic osteomalacia due to renal phosphate wasting (Nelson et al. 1997, Drezner 2000). Patients affected by OOM exhibit biochemical characteristics that are similar to those observed in XLH patients. The disease is usually caused by inconspicuous benign tumors that may be found in a variety of different locations. If the tumors are localized and successfully removed, there is prompt improvement of the symptoms, and phosphate homeostasis is rapidly normalized. This strongly suggests that a tumor-derived humoral factor, such as the proposed phosphatonin, causes phosphate depletion by acting on the proximal tubule cells to increase urinary phosphate excretion. Several groups have attempted to characterize the putative phosphaturic factor by different approaches. For example, extracts from OOM tumors were shown to be phosphaturic when injected into dogs, rats or mice, and to inhibit the production of $1,25(\mathrm{OH})_{2} \mathrm{D}_{3}$ in primary kidney cell cultures (Aschinberg et al. 1977, Lau et al. 1979, Popovtzer 1981, Miyauchi et al. 1988). Others have shown that conditioned medium from primary cultures of tumor cells inhibits phosphate uptake by opossum kidney (OK) cells (Cai et al. 1994, Wilkins et al. 1995, Nelson et al. 1996). However, attempts to elucidate the chemical nature of the OOM factor have yielded conflicting results. For example, the proposed entity has been found to be heat labile or heat resistant (Miyauchi et al. 1988, Cai et al. 1994, Wilkins et al. 1995, Nelson et al. 1999), to be trypsin sensitive or trypsin insensitive (Miyauchi et al. 1988, Cai et al. 1994, Wilkins et al. 1995, Nelson et al. 1996) and to have a molecular weight of $56 \mathrm{kDa}, 8-25 \mathrm{kDa}$ or less than $5 \mathrm{kDa}$ (Cai et al. 1994, Rowe et al. 1996, Nelson et al. 1999).

Thus, based on the similarities of the laboratory and clinical findings in patients affected by XLH and OOM, it appears plausible that both disorders are caused by increased production/activity of the same phosphaturic factor. However, the identity of this proposed factor remains elusive. To gain further insights into its nature, we generated and characterized extracts from several different OOM tumors.

\section{Materials and Methods}

\section{Materials}

Human [Y34]PTH(1-34)amide (subsequently referred to as $\mathrm{PTH}$ ) was synthesized by the biopolymer synthesis facility at Massachusetts General Hospital (Boston, MA, USA). Centricon and microcon spin filters were purchased from Millipore (Bedford, MA, USA). Sequencing grade trypsin was purchased from Promega (Madison, WI, USA). Papain and proteinase $\mathrm{K}$ were from Roche Molecular Biochemicals (Mannheim, Germany), the C8 Brownlee microbore column $(2.1 \times 100 \mathrm{~mm})$ was from Perkin-Elmer Applied Biosystems (Foster City, CA, USA). Dulbecco's minimal essential medium (DMEM)/ HAM-F12 and fetal calf serum (FCS) were from Life Technologies (Grand Island, NY, USA), ${ }^{32} \mathrm{P}-$ orthophosphate $(2 \mathrm{mCi} / \mathrm{ml})$ was from New England Nuclear (Boston, MA, USA), and the BCA protein assay was from Pierce (Rockford, IL, USA). All other reagents were of the highest available purity and were obtained through Fisher Scientific (Pittsburgh, PA, USA).

\section{Patients and tissue extraction}

Extracts were generated from four different tumors, some of which have been described previously; a mandibular tumor from a 31-year-old Korean female (Yang et al. 1997) (tumor A), a tumor in the adductor channel of the left thigh from a 31-year-old Swedish male (Nelson et al. 1998) (tumor B), a tumor which was removed in March 1998 from the sole of the foot of a German female (tumor C), and a tumor from the left thigh of a 54-year-old Japanese male (Miyauchi et al. 1988) (tumor D). All patients had presented with biochemical findings characteristic of OOM, which dramatically improved after surgery. All tumors were instantly frozen after removal from the patients and stored at $-70{ }^{\circ} \mathrm{C}$ until used in this study. Pieces of tumor or control tissues (parathyroid, liver, and kidney) (75-250 mg) were removed from frozen samples and were homogenized on ice using a glass tissue grinder in $100-500 \mu \mathrm{l}$ ice-cold normal saline. The homogenates were transferred into microfuge tubes and spun at $4{ }^{\circ} \mathrm{C}(20000 \mathrm{~g} ; 5 \mathrm{~min})$. The supernatants were transferred into fresh tubes and protein content was measured using the Pierce BCA protein assay; bovine serum albumin was used as a standard. The protein concentration was subsequently adjusted to $2 \mathrm{mg} / \mathrm{ml}$.

\section{Phosphate uptake assay}

OK cells were grown in DMEM/HAM-F12 supplemented with $5 \%$ FCS and $1 \%$ penicillin/streptomycin $(5000 \mathrm{IU} / \mathrm{ml}, 5 \mathrm{mg} / \mathrm{ml})$. Cells were trypsinized and $5 \times 10^{4}$ cells were then seeded into the inner 24 wells of a 48-well tissue culture plate. After reaching confluency, 
the cells were cultured for 2 more days before performing experiments. To assess phosphate uptake, the medium (two wells/data point) was replaced with medium containing tumor extracts (concentration: 2.5\%, v/v; unless otherwise indicated) or vehicle (equal volume of saline). After $12 \mathrm{~h}$, cells were rinsed twice with uptake buffer $\left(150 \mathrm{mM} \mathrm{NaCl}, 5 \mathrm{mM} \mathrm{KCl}, 1 \mathrm{mM} \mathrm{CaCl}_{2}, 5 \mathrm{mM}\right.$ glucose, and $10 \mathrm{mM}$ cyclohexylaminopropane sulfonic acid, $\mathrm{pH}$ 9.5), before adding $100 \mu \mathrm{l} /$ well of the same buffer supplemented with $5 \times 10^{5}$ c.p.m. of ${ }^{32} \mathrm{P}-$

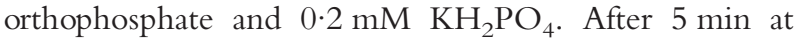
$37^{\circ} \mathrm{C}$, the reaction was interrupted by rapidly aspirating the buffer and replacing it with $250 \mu$ ice-cold 'STOP' solution $(5 \mathrm{mM}$ sodium arsenate and $150 \mathrm{mM}$ choline chloride, $\mathrm{pH} 7 \cdot 4)$. The cells were subsequently lysed with $0.5 \mathrm{M} \mathrm{NaOH}(250 \mu \mathrm{l})$ and total radioactivity of the lysate was measured in a liquid scintillation counter. In protease inactivation experiments, the extracts were pretreated using the following experimental conditions: trypsin $(50 \mu \mathrm{g} / \mathrm{ml}), 37^{\circ} \mathrm{C}, 12 \mathrm{~h}$ in $10 \mathrm{mM}$ Tris, $\mathrm{pH} 8 \cdot 0$; papain $(50 \mu \mathrm{g} / \mathrm{ml}), 37^{\circ} \mathrm{C}, 12 \mathrm{~h}$ in $10 \mathrm{mM}$ Tris, $\mathrm{pH} 7 \cdot 0$; proteinase $\mathrm{K}(100 \mu \mathrm{g} / \mathrm{ml}), 50{ }^{\circ} \mathrm{C}, 12 \mathrm{~h}$ in $10 \mathrm{mM}$ Tris, $\mathrm{pH} 8 \cdot 0$ with $0 \cdot 1 \%$ SDS.

\section{Stimulation of $C A M P$ accumulation}

Confluent OK cells were rinsed with ice-cold phosphatebuffered saline and $100 \mu$ IBMX buffer (DMEM containing $2 \mathrm{mM}$ isobutylmethylxanthine (IBMX), $1 \mathrm{mg} / \mathrm{ml}$ bovine serum albumin and $35 \mathrm{mM}$ Hepes $-\mathrm{NaOH}, \mathrm{pH}$ $7 \cdot 4)$ containing either tumor extract $(2 \cdot 5 \%, \mathrm{v} / \mathrm{v}), \mathrm{PTH}$ $(1 \mu \mathrm{M})$ or vehicle (normal saline $2 \cdot 5 \%, \mathrm{v} / \mathrm{v}$ ). The same procedure was used to stimulate cAMP accumulation in ROS 17/2 8, UMR106, or LLC-PK1 cells stably expressing either the PTH/PTH-related protein (PTHrP) or the PTH-2 receptor (Carter et al. 1999). After incubating the plates for $1 \mathrm{~h}$ at room temperature, the buffer was completely removed, the plates were placed on powdered dry ice, and intracellular cAMP was extracted by adding $250 \mu \mathrm{l} 10 \mathrm{mM} \mathrm{HCl}$. The cell extracts were analyzed in duplicates for cAMP content by radioimmunoassay (RIA) as described (Carter et al. 1999).

\section{HPLC fractionation}

About $100 \mu \mathrm{l}$ of each crude tumor extract was diluted with $\mathrm{H}_{2} \mathrm{O}$ (1:1) before centrifugation $(14000 \mathrm{~g}$, $45 \mathrm{~min}$ at $4{ }^{\circ} \mathrm{C}$ ) through a microcon filter with a cut-off of $3 \mathrm{kDa}$. After lyophilization, the flow-through was reconstituted with $100 \mu \mathrm{H} \mathrm{H}_{2} \mathrm{O} / 0 \cdot 1 \%$ trifluoroacetic acid (TFA) and the entire sample was injected onto a C8 microbore column $(2.1 \times 100 \mathrm{~mm})$; the following gradient and solvents were used: initial condition, $98 \%$ solution A $(0 \%$ acetonitrile (ACN), $0.06 \%$ TFA in $\mathrm{H}_{2} \mathrm{O}$ ) and $2 \%$ solution $\mathrm{B}(80 \%$ ACN, $0 \cdot 05 \%$ TFA in $\mathrm{H}_{2} \mathrm{O}$ ) followed by a $2-95 \%$ solution $\mathrm{B}$ gradient over $80 \mathrm{~min}$; the flow rate was $100 \mu \mathrm{l} / \mathrm{min}$,
$200 \mu \mathrm{l}$ were collected per fraction. After lyophilization, fractions were dissolved in $200 \mu \mathrm{l}$ culture medium and the reconstituted samples $(100 \mu \mathrm{l} /$ well $)$ were tested for inhibition of phosphate uptake using OK cells as described above.

\section{Results}

To determine whether OOM tumors produce a factor(s) that inhibits phosphate uptake in OK cells, we generated several independent extracts from four different tumors and tested their ability to inhibit the uptake of ${ }^{32} \mathrm{P}-$ orthophosphate by these cells. Three extracts induced significant inhibition of ${ }^{32} \mathrm{P}$ transport but their individual efficacy varied considerably. For example, extract A was most efficacious and reduced ${ }^{32} \mathrm{P}$ uptake to $42 \pm 5 \%$ of the uptake in untreated control cells (Fig. 1A). This effect was similar to that of extracts derived from a parathyroid adenoma. Extracts from tumors B and C were less efficacious and inhibited ${ }^{32} \mathrm{P}$ uptake to only $69 \pm 5 \%$ and $71 \pm 5 \%$ of control respectively. In contrast, extracts from tumor $\mathrm{D}$ inhibited only to $86 \pm 4 \%$. We also generated extracts from kidney and liver, and found that these control extracts displayed an inhibitory activity that was comparable with that observed with extract D (Fig. 1A).

To explore the possibility that the tumor extracts mediated their activity through a $G$ protein-coupled receptor, we measured cAMP accumulation in response to the different extracts. The three tumor extracts that had shown significant inhibition of ${ }^{32} \mathrm{P}$ uptake also induced cAMP accumulation in the OK cells whereas extracts from liver, kidney, and tumor D did not (Fig. 1B). As expected, a strong cAMP response was induced by the parathyroid adenoma extract. To determine whether the cAMP response could be observed in cells other than the OK cells, we tested two other clonal osteoblast-like cell lines, ROS 17/2.8 and UMR106, as well as LLC-PK1 cells stably expressing either the recombinant human PTH/ PTHrP receptor or the human PTH-2 receptor (Carter et al. 1999). When challenged with PTH, each of these cell lines responded with an increase in cAMP accumulation, but not when treated with any of the tumor extracts (data not shown). In addition, UMR106 cells responded to isoproterenol and dopamine, and ROS $17 / 2 \cdot 8$ cells responded to prostaglandin $\mathrm{E} 2$ and isoproterenol.

To further characterize the factor(s) that inhibits ${ }^{32} \mathrm{P}$ uptake, the most potent extract was studied in more detail in dose-response and time-course experiments. Tumorinduced inhibition of phosphate uptake was already apparent after $2 \mathrm{~h}$ and reached maximal levels after $12 \mathrm{~h}$ which was very similar to the effects induced by PTH (Fig. 2A). We next compared the inhibition induced by different dilutions of extract $\mathrm{A}$ with that induced by increasing concentrations of PTH, and found 
A

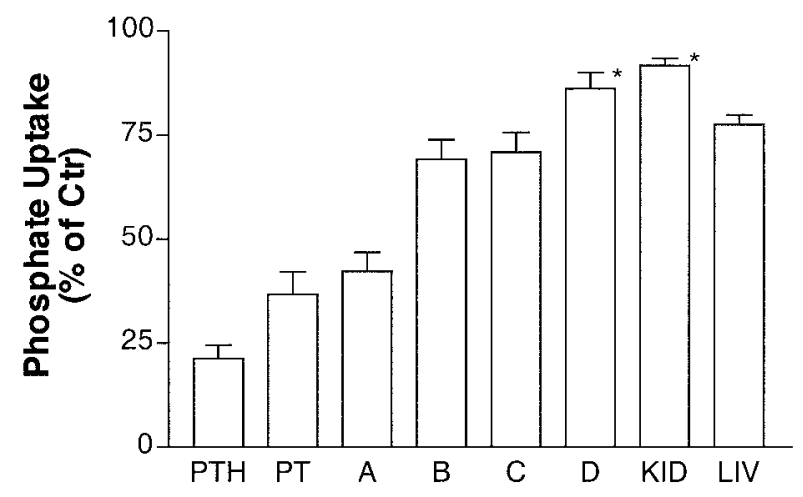

B

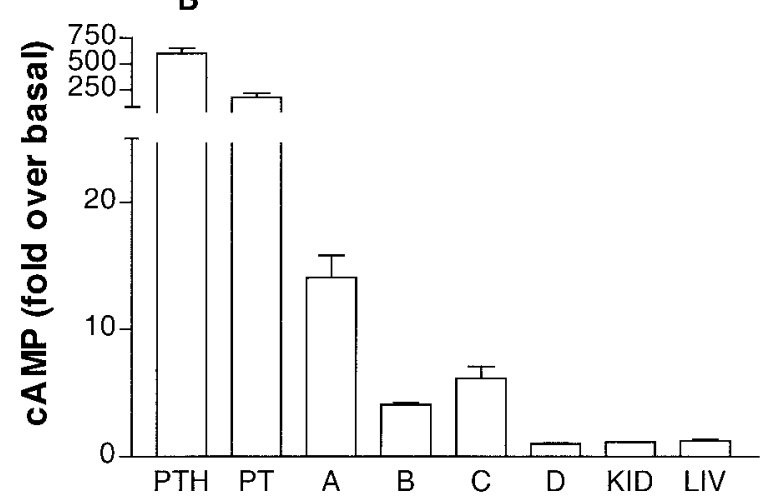

Figure 1 Effects of crude aqueous extracts from OOM tumors on phosphate transport in OK cells. OK cells were grown to confluency before treatment with PTH $(1 \mu \mathrm{M})$ or tissue extracts $(2 \cdot 5 \%, \mathrm{v} / \mathrm{v})$. (A) After a 12-h incubation, uptake of

${ }^{32} \mathrm{P}$-orthophosphate was measured over a 5 -min period as described in Materials and Methods. Inhibition of phosphate uptake is expressed as percent of the uptake of non-treated control (Ctr) cells. *Not significantly different from untreated control using ANOVA. (B) After a 1-h incubation, intracellular cAMP was extracted from the cell layer and measured by RIA. Results are expressed as fold over basal cAMP accumulation in vehicle-treated cells. All data are shown as means \pm S.E.M. and are derived from at least six independent experiments for (A) and from two independent experiments for (B). PTH:

[Tyr34]hPTH(1-34)amide (1 $\mu \mathrm{M})$; PT: extract from parathyroid adenoma $(2.5 \%) ; \mathrm{A}, \mathrm{B}, \mathrm{C}$, and D: extracts from the different tumors (2.5\%); KID: kidney extract ( $2 \cdot 5 \%)$; LIV: liver extract ( $2 \cdot 5 \%)$.

that approximately $0 \cdot 6 \%(\mathrm{v} / \mathrm{v})$ of this extract was as potent as $10 \mathrm{nM} \mathrm{PTH}$. Furthermore, the dose-response curves for PTH and extract A ran in parallel over the entire range tested (Fig. 2B).

In an attempt to partially purify the activity identified in the tumor extracts, we first used centrifugation filters with different molecular weight cut-offs. Stimulation of cAMP accumulation and inhibition of ${ }^{32} \mathrm{P}$ uptake was primarily recovered in the flow-through, even when using filters with a $3 \mathrm{kDa}$ cut-off. These findings suggested that both activities are due to low molecular weight compounds. Fractionation of the flow-through by C8 microbore HPLC revealed two peaks with biological activity when tested in the OK cell assay. For all three tumor extracts, fraction no. 2 (i.e. the flow-through) stimulated the accumulation of cAMP and inhibited ${ }^{32} \mathrm{P}$ uptake. For extract $\mathrm{A},{ }^{32} \mathrm{P}$ uptake was also inhibited by material eluting in fraction nos 23-24; these fractions failed to stimulate cAMP accumulation (Fig. $3 \mathrm{~A}$ and $\mathrm{B}$ ).

To further characterize the chemical nature of the biologically active compounds detected in extract A, aliquots were either heated to $99^{\circ} \mathrm{C}$ or treated with one of several different proteases. Heating for $1 \mathrm{~h}$ failed to diminish the activity of extract A (Fig. 4). Also, the activity of synthetic PTH or parathyroid extracts remained unaffected. The tumor extract was furthermore resistant to trypsin, proteinase $\mathrm{K}$, and papain, although these enzymes efficiently abolished the capacity of synthetic PTH and parathyroid extracts to reduce ${ }^{32} \mathrm{P}$ uptake by OK cells (Fig. 4); despite proteinase or heat treatment, cAMP accumulation by the unfractionated tumor extracts remained unchanged (data not shown).

\section{Discussion}

Tumors that cause OOM secrete a factor(s) that acts directly or indirectly on the kidney to reduce, through yet unknown mechanisms, the reabsorption of phosphate in the proximal tubules. This OOM-derived factor is thought to act through a specific cell surface receptor on the kidney cells and activation of this receptor may either accelerate the degradation of NPT-2 protein or its mRNA and/or diminish new synthesis. Based on this hypothesis and knowledge of the biochemical findings in OOM patients, different cell-based in vitro assays have been devised to assess the effects of the phosphaturic factor. For example, the inappropriately low serum concentration of $1,25(\mathrm{OH})_{2} \mathrm{D}_{3}$ in OOM patients indicates that phosphatonin inhibits the renal $1 \alpha$-hydroxylase. Accordingly, OOM tumor extracts were shown to reduce the $1 \alpha$ hydroxylation of 25 hydroxyvitamin $\mathrm{D}_{3}$ in primary renal cell cultures (Miyauchi et al. 1988). Another approach, which was used in the present study, takes advantage of NPT-2-dependent transport of radioactive phosphate across the plasma membrane of $\mathrm{OK}$ cells. These cells express, in addition to NPT-2, the PTH/PTHrP receptor. When activated by PTH (or PTHrP), events downstream of this $G$ protein-coupled receptor lead to the rapid degradation of this sodium-phosphate cotransporter (Murer et al. 1999). Consequently, OK cells respond to challenge with PTH (or PTHrP) with a reduction in ${ }^{32} \mathrm{P}$ uptake, thus mimicking the in vivo effects of the hormone. Several groups have previously shown that medium conditioned by cells derived from OOM tumors, as well as 

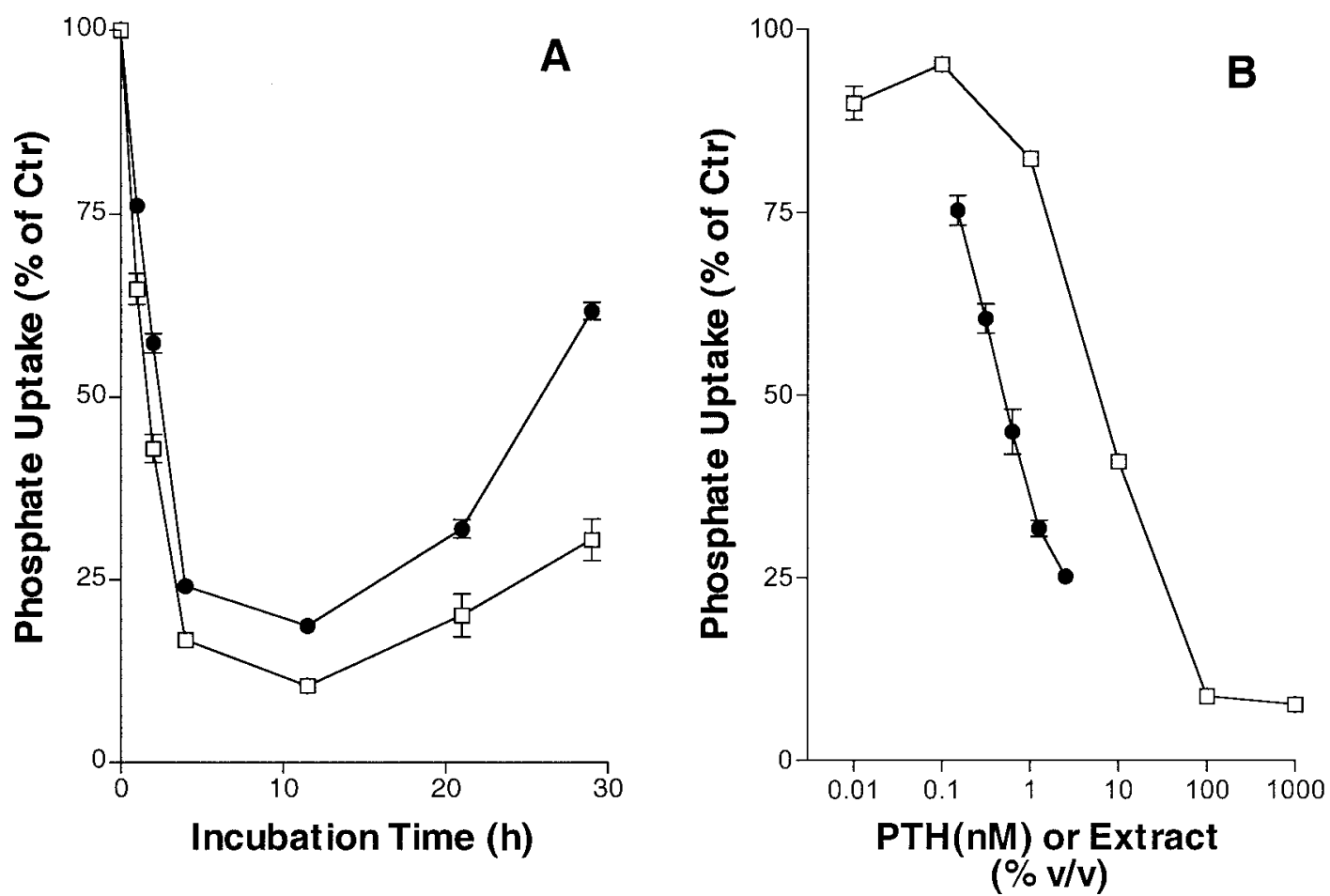

Figure 2 Time-course and dose-response effects of the extract A in comparison with PTH. OK cells were grown to confluency before treatment with PTH or extract A. After the indicated time-periods, uptake of ${ }^{32} \mathrm{P}$-orthophosphate was measured over a 5-min period as described in Materials and Methods. Inhibition of phosphate uptake was expressed as percent of the uptake in non-treated control $(\mathrm{Ctr})$ cells. The graphs show the means \pm S.E.M. of uptake in duplicate wells in a single representative experiment. Similar results were observed in two additional experiments. (A) Time-course experiment: OK cells in 48-well plates were rinsed and fresh medium was added. At the indicated times before measuring phosphate uptake, cells were treated with $1 \mu \mathrm{M} \mathrm{PTH}(1-34)(\square)$ or $2.5 \%$ of extract $\mathrm{A}(\mathbf{O})$. (B) Dose-response experiment: $[\mathrm{Tyr} 34] \mathrm{hPTH}(1-34)$ amide $(\square)$ and extract $\mathrm{A}(\boldsymbol{\bullet})$ were serially diluted and OK cells were treated for $12 \mathrm{~h}$ before measuring uptake of ${ }^{32} \mathrm{P}$-orthophosphate.

serum from either OOM patients or hyp mice, inhibit ${ }^{32} \mathrm{P}$ uptake by OK cells, thus supporting the hypothesis that these cells also express the putative phosphatonin receptor (Cai et al. 1994, Lajeunesse et al. 1996, Nelson et al. 1996, 1998).

We had the opportunity to characterize, under standardized conditions, aqueous extracts from four different tumors that clearly gave rise to OOM. This allowed us to extend previous studies which had investigated, in most cases, only a single tumor and had provided conflicting results. For example, some investigators observed an inhibition of phosphate uptake by OK cells (Cai et al. 1994, Wilkins et al. 1995, Nelson et al. 1998), an inhibition of 1 $\alpha$-hydroxylase activity (Miyauchi et al. 1988), or phosphaturia in live animals (Miyauchi et al. 1988), while others failed to detect any in vitro changes (Shane et al. 1997). These inconsistencies may be due to differences in experimental techniques or could be related to heterogeneity among or within different tumors. Thus, it is not surprising that we also found strong variability regarding the inhibition induced by the different tumors. For example, extract A produced consistent inhibition of ${ }^{32} \mathrm{P}$ uptake that was similar to the effect induced by synthetic PTH. In contrast, extracts from two other tumors, B and $\mathrm{C}$, had only a weak effect and a fourth extract, derived from tumor $\mathrm{D}$, showed no effect at all. These findings could imply that the phosphaturic entity differs among tumors, that different tumors produce varying quantities of the same substance, that the phosphaturic factor is produced only in a small portion of each tumor, or that the biologically active factor requires co-factors. It is also possible that prolonged storage, even at $-80^{\circ} \mathrm{C}$, can cause a loss of biological activity and this might explain the almost complete lack of inhibitory activity in tumor D.

The dose-response and time-course of the inhibition induced by extract A was similar to the inhibition induced by PTH. This could indicate that the events induced by PTH and the OOM factor converge on a common downstream signaling pathway, supporting the conclusion that the effects of extract A are mediated by a receptorcoupled mechanism. This raises the question as to whether tumor extracts and PTH activate a common second 

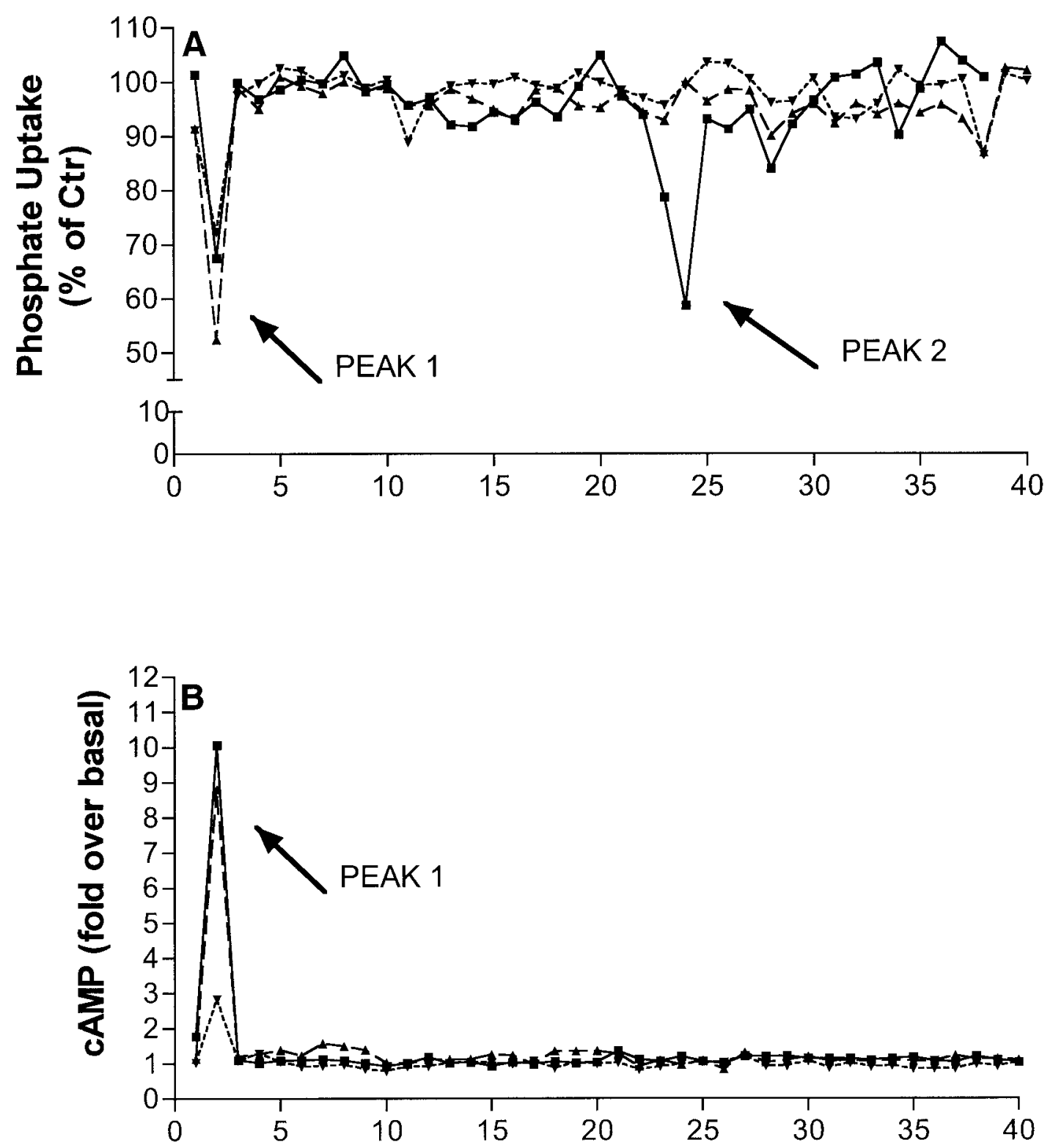

Fraction number

Figure 3 HPLC fractionation of tumor extracts provides evidence for two distinct factors that inhibit phosphate uptake by OK cells. Size-selected tumor extracts $(<3 \mathrm{kDa})$ were fractionated on a C8 microbore HPLC column and the different fractions were assayed for their ability to inhibit ${ }^{32} \mathrm{P}$ uptake and to stimulate cAMP accumulation. (A) One half of each collected fraction was lyophilized and subsequently dissolved in $200 \mu$ l culture medium. OK cells in duplicate wells were then incubated with the reconstituted fractions for $12 \mathrm{~h}$ before determining the uptake of ${ }^{32}$ P-orthophosphate over a 5-min period. (B) The other half of each collected fraction was lyophilized and dissolved in $200 \mu \mathrm{l}$ culture medium containing IBMX. Duplicate wells with OK cells were then incubated with the reconstituted fractions for $1 \mathrm{~h}$ and the intracellular cAMP accumulation was determined by RIA. The means of the duplicate data points are plotted in the graphs and the arrows indicate the position of peaks with significant activity. Solid line tumor A; dashed line: tumor B $(\boldsymbol{\Delta})$ and dotted line: tumor $C(\boldsymbol{\nabla})$.

messenger pathway. Previously, conflicting results have been reported regarding the ability of tumor derivatives to stimulate cAMP accumulation. Seshhadri et al. (1985) found a potent stimulatory effect of three tumor extracts on the accumulation of cAMP in chicken renal plasma membranes and Nelson et al. (1996) found that media 


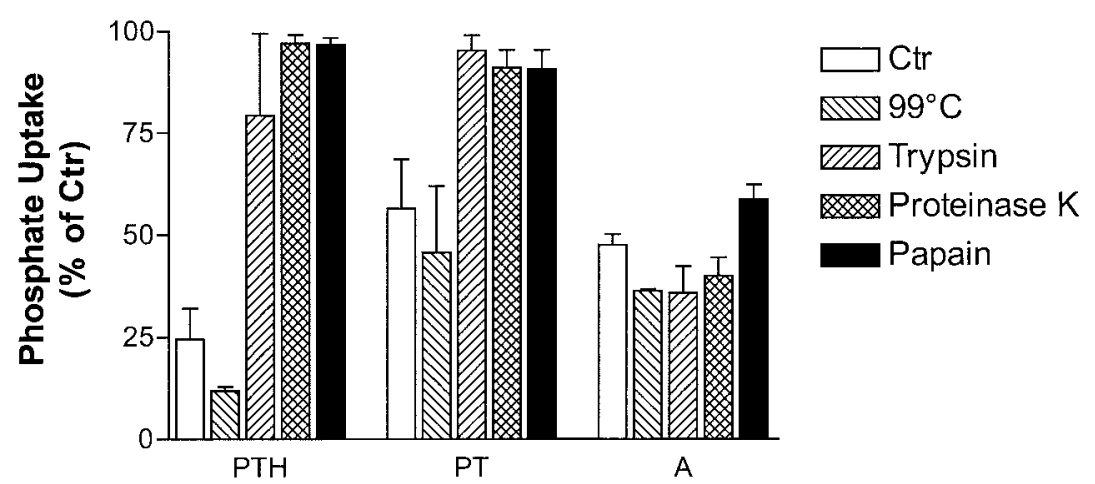

Figure 4 Protease and heat treatment of extract $\mathrm{A}$ in comparison with synthetic PTH and parathyroid extract. Extracts from tumor A and a parathyroid adenoma (1.25\% of the final volume of medium) were pretreated with the indicated enzymes as described in Materials and Methods or were heated to $99{ }^{\circ} \mathrm{C}$ for $1 \mathrm{~h}$. OK cells were then incubated with these extracts for $12 \mathrm{~h}$ before the uptake of ${ }^{32} \mathrm{P}$-orthophosphate was measured over a 5 -min period. The graph shows mean \pm S.E.M. uptake of duplicate wells from two independent experiments. PTH: [Tyr34]hPTH(1-34)amide; PT: extract from parathyroid adenoma; A: extract from tumor $\mathrm{A}$.

conditioned by primary cultures of an OOM tumor stimulated cAMP accumulation in UMR, but not in OK cells. Similarly, Miyauchi et al. (1988) found no cAMP response in primary renal cells when using an extract from a different tumor and Cai et al. (1994) were unable to detect cAMP accumulation in response to medium conditioned by tumor cells. In the present study, we found a cAMP-stimulatory activity in three of four tumor extracts, but only when using OK cells. Furthermore, for each of these three tumor extracts, the cAMP response correlated with the inhibition of ${ }^{32} \mathrm{P}$ uptake. In contrast, extract $\mathrm{D}$, as well as extracts from two control tissues, kidney and liver, showed only little inhibition of ${ }^{32} \mathrm{P}$ uptake and failed to stimulate cAMP accumulation. However, the overall cAMP response was weak when compared with that induced by $\mathrm{PTH}$, indicating that the inhibition of ${ }^{32} \mathrm{P}$ uptake may not be directly linked to the cAMP pathway.

Previous attempts to characterize the OOM factor chemically have yielded conflicting results. For example, based on dialysis experiments, one group suggested that the tumor-derived activity was larger than $8 \mathrm{kDa}$, but smaller than $25 \mathrm{kDa}$ (Cai et al. 1994). Similar to our findings, a more recent preliminary report provided evidence for a low molecular weight entity that was resistant to several different proteinases, including trypsin and proteinase K (Nelson et al. 1999). Consistent with this latter finding, we found that tumor extract A could not be inactivated by various proteases. This could imply that the activity inhibiting phosphate transport is not a protein. In an attempt to partially purify the tumor-derived inhibitory factor(s), we obtained evidence for two different peaks of activity. First, we repeatedly and uniformly observed that all inhibitory activity was filtered through membranes with a cut-off of $3 \mathrm{kDa}$, suggesting a low molecular weight entity (note that synthetic PTH with a molecular weight of $4 \cdot 1 \mathrm{kDa}$ was retained only partially by this filter). When fractionated by HPLC, the inhibitory activity was detected for all crude extracts in the flow-through (fraction no. 2), indicating that the $\mathrm{C} 8$ reverse-phase resin did not retain the factor. Extract A contained a second fraction with inhibitory activity, most likely explaining the higher efficacy of this extract. It is, however, possible that this second peak of inhibitory activity is present also in the other extracts, but in smaller quantities, making it necessary to fractionate larger amounts of tumor extract. The significant retention of inhibitory activity on the $\mathrm{C} 8$ reverse-phase resin may indicate that the biologically active factor is a small peptide with an amino acid sequence not recognized by the investigated enzymes or an amino acid derivative. In this regard, it is interesting to note that a fibroblast growth factor (FGF)-like molecule, FGF-23, was recently found to be mutated in patients with autosomal dominant hypophosphatemic rickets (White et al. 2000) and that the mRNA encoding this protein is expressed abundantly by all of the tumors described herein (White et al. 2001). It remains to be determined, however, whether FGF-23 or fragments thereof can induce phosphaturia in vivo or inhibit phosphate uptake in OK cells. Organic compounds with the ability to inhibit phosphate uptake, such as steroids or prostaglandins, cannot be ruled out but seem less likely because of the aqueous nature of the extracts. Furthermore, prostaglandin E2, $\beta$-adrenergic agents and dopamine, a known inhibitor of ${ }^{32} \mathrm{P}$ uptake in OK cells (Baines \& Drangova 1998), are not likely candidates, since the tumor extracts failed to stimulate cAMP accumulation in UMR106 and ROS $17 / 2 \cdot 8$ cells.

In conclusion, we have shown that low molecular weight molecules extracted from OOM tumors inhibit phosphate uptake in OK cells, but it remains uncertain 
whether these are related to or derived from the longsought phosphaturic factor that is thought to be produced by OOM tumors.

\section{Acknowledgements}

This work was supported by grants from The Swedish Society of Medicine, Wenner-Gren Foundations, The Swedish Foundation for International Cooperation in Research and Higher Education, and the Swedish Institute. We wish to thank Ashok Khatri for technical assistance and fruitful discussion.

\section{References}

Aschinberg LC, Solomon LM, Zeis PM, Justice P \& Rosenthal IM 1977 Vitamin D-resistant rickets associated with epidermal nevus syndrome: demonstration of a phosphaturic substance in the dermal lesions. Journal of Pediatrics 91 56-60.

Baines AD \& Drangova R 1998 Does dopamine use several signal pathways to inhibit Na-Pi transport in OK cells? Journal of the American Society of Nephrology 9 1604-1612.

Beck L, Soumounou Y, Martel J, Krishnamurthy G, Gauthier C, Goodyer CG \& Tenenhouse HS 1997 Pex/PEX tissue distribution and evidence for a deletion in the $3^{\prime}$ region of the Pex gene in X-linked hypophosphatemic mice. Journal of Clinical Investigation 99 1200-1209.

Cai Q, Hodgson SF, Kao PC, Lennon VA, Klee GG, Zinsmiester AR \& Kumar R 1994 Brief report: inhibition of renal phosphate transport by a tumor product in a patient with oncogenic osteomalacia. New England Journal of Medicine 330 1645-1649.

Carter PH, Jüppner H \& Gardella TJ 1999 Studies of the N-terminal region of a parathyroid hormone-related peptide (1-36) analog: receptor subtype-selective agonists, antagonists, and photochemical cross-linking agents. Endocrinology 140 4972-4981.

Drezner MK 1996 Phosphorus homeostasis and related disorders. In Principles in Bone Biology, pp 263-276. Eds JP Bilezikian, LG Raisz \& GA Rodan. New York: Academic Press.

Drezner MK 2000 PHEX gene and hypophosphatemia Kidney International 57 9-18.

Du L, Desbarats M, Viel J, Glorieux FH, Cawthorn C \& Ecarot B 1996 cDNA cloning of the murine Pex gene implicated in $\mathrm{X}$-linked hypophosphatemia and evidence for expression in bone. Genomics 36 22-28.

Econs MJ 1999 New insights into the pathogenesis of inherited phosphate wasting disorders. Bone 25 131-135.

Econs MJ \& Drezner MK 1994 Tumor-induced osteomalacia unveiling a new hormone. New England Journal of Medicine 330 1679-1681.

Lajeunesse D, Meyer RA Jr \& Hamel L 1996 Direct demonstration of a humorally-mediated inhibition of renal phosphate transport in the Hyp mouse. Kidney International 50 1531-1538.

Lau K, Stom MC, Goldberg M, Goldfarb S, Gray RW, Lemann J \& Agus Z 1979 Evidence for a humoral phosphaturic factor in oncogenic hypophosphatenic osteomalacia. Clinical Research 27 421A.

Miyauchi A, Fukase M, Tsutsumi M \& Fujita T 1988 Hemangiopericytoma-induced osteomalacia: tumor transplantation in nude mice causes hypophosphatemia and tumor extracts inhibit renal 25-hydroxyvitamin D 1-hydroxylase activity. Journal of Clinical Endocrinology and Metabolism 67 46-53.
Murer H, Forster I, Hernando N, Lambert G, Traebert M \& Biber J 1999 Posttranscriptional regulation of the proximal tubule $\mathrm{NaPi}-\mathrm{II}$ transporter in response to PTH and dietary P(i). American Journal of Physiology 277 F676-F684.

Nelson AE, Namkung HJ, Patava J, Wilkinson MR, Chang AC, Reddel RR, Robinson BG \& Mason RS 1996 Characteristics of tumor cell bioactivity in oncogenic osteomalacia. Molecular and Cellular Endocrinology 124 17-23.

Nelson AE, Robinson BG \& Mason RS 1997 Oncogenic osteomalacia: is there a new phosphate regulating hormone? Clinical Endocrinology 47 635-642.

Nelson A, Hogan J, Ljunggren O, Diamond T, Robinson B \& Mason R 1998 Phosphate uptake inhibitory bioactivity in serum of patients with oncogenic osteomalacia. Bone 23 S460.

Nelson AE, Robinson BG, Holm IA, Hogan JJ \& Mason RS 1999 Further characterisation of the phosphate transport regulating factor in oncogenic osteomalacia and mutation analysis of the PHEX gene in tumor cell DNA. Journal of Bone and Mineral Research 14 S325.

Popovtzer MM 1981 Tumor-induced hypophosphatemic osteomalacia: evidence for a phosphaturic cAMP-independent action of tumor extract. Clinical Research 29 418A.

Rowe PS, Ong AC, Cockerill FJ, Goulding JN \& Hewison M 1996 Candidate 56 and $58 \mathrm{kDa}$ protein(s) responsible for mediating the renal defects in oncogenic hypophosphatemic osteomalacia. Bone 18 159-169.

Ruchon AF, Marcinkiewicz M, Siegfried G, Tenenhouse HS, DesGroseillers L, Crine P \& Boileau G 1998 Pex mRNA is localized in developing mouse osteoblasts and odontoblasts. Journal of Histochemistry and Cytochemistry 46 459-468.

Seshadri MS, Cornish CJ, Mason RS \& Posen S 1985 Parathyroid hormone-like bioactivity in tumours from patients with oncogenic osteomalacia. Clinical Endocrinology 23 689-697.

Shane E, Parisien M, Henderson JE, Dempster DW, Feldman F, Hardy MA, Tohme JF, Karaplis AC \& Clemens TL 1997 Tumor-induced osteomalacia: clinical and basic studies. Journal of Bone and Mineral Research 12 1502-1511.

Tenenhouse HS 1999 X-linked hypophosphataemia: a homologous disorder in humans and mice. Nephrology, Dialysis, Transplantation 14 333-341.

The-HYP-Consortium 1995 A gene (PEX) with homologies to endopeptidases is mutated in patients with X-linked hypophosphatemic rickets. Nature Genetics 11 130-136.

White KE, Evans WE, O’Riordan JL, Speer MC, Econs MJ, Lorenz-Depiereux B, Grabowski M, Meitinger T \& Strom TM 2000 Autosomal dominant hypophosphataemic rickets is associated with mutations in FGF23. Nature Genetics 26 345-348.

White KE, Jonsson KB, Carn G, Hampson G, Spector TD, Mannstadt M, Lorenz Depiereux B, Miyauchi A, Yang IM, Ljunggren Ö, Meitinger T, Strom T, Jüppner H \& Econs M 2001 The autosomal dominant hypophosphatemic rickets gene is a secreted polypeptide over expressed by tumors that cause phosphate wasting. Journal of Clinical Endocrinology and Metabolism 28 268-274.

Wilkins GE, Granleese S, Hegele RG, Holden J, Anderson DW \& Bondy GP 1995 Oncogenic osteomalacia: evidence for a humoral phosphaturic factor. Journal of Clinical Endocrinology and Metabolism $801628-1634$.

Yang IM, Park YK, Hyun YJ, Kim DY, Woo JT, Kim SW, Kim JW, Kim YS \& Choi YK 1997 Oncogenic osteomalacia caused by a phosphaturic mesenchymal tumor of the oral cavity: a case report. Korean Journal of Internal Medicine 12 89-95.

Received in final form 29 January 2001

Accepted 14 February 2001 